\title{
Insurgency, Political Stability and Economic Performance in Post-Saddam Iraq: An Evaluation
}

\author{
Abdul Wahed Jalal Nore \& Ahmad Bashawir Abdul Ghani \\ University Utara Malaysia \\ E-mail: bashawir@uum.edu.my
}

\begin{abstract}
On March 20, 2003, the coalition forces headed by the United States of America launched Operation Iraqi Freedom to remove the regime of Saddam Hussein. By mid-April, major fighting was essentially over, and on May 1, the United States declared an end to major combat operations. With that declaration, the coalition forces faced with a very serious challenge to ensure stability in the post-conflict period and a peaceful political transition to a new and democratic Iraqi government. However, despite the continuing power of insurgency and the sectarian violence, Iraq is gradually gearing into a kind of constitutional process and political development. The election of January 2005, the negotiation of the constitution in the summer of that year, the referendum of October 15, which ratified the constitution and the second general election in mid December, all is a sign of functioning of political and constitutional development. The new constitution was written with the hope that for the diverse groups in Iraq to run their mutual relations in such a way that the dialogue between fighting parties shifts from a battle field into a political settlement. However, such political settlement, in spite of the huge presence of US forces, has been extremely slow. Domestic political elites have shown very little concern to develop the nature of consensus while dealing with the issues of crucial importance for Iraq and its citizens.
\end{abstract}

Keywords: Insurgency, Political stability, Economic Performance, Consociatianal Democracy, Corruption.

\section{Introduction}

In this article we will analyze the nature and intensity of political stability and instability in the post-Saddam Iraq. Arend Lijphart defines political stability as the "system's ability to survive intact" (Note 1) and "the one in which the capabilities of the system are sufficient to meet the demands placed upon it." (Note 2) One of the important factors for a government to function in a multiethnic society is consensus and accommodation among the political elites who represent various segments of society. In the Iraqi context the segmented identity deepened in post Saddam-Iraq.

Admittedly the major elements of (consociational) or power sharing democracy such as suitable segment size, multiparty system and segmental isolation do exist in Iraq. Iraqi political elites, however, have not been able to reach political consensus on most of the things which are of the utmost importance for the normal functioning of the state. The absence of consensus about the state itself and absence of consensus regarding the political arrangement of the state are the two most important elements that obstruct political elites' accommodative politics.

In April 20, 2005, a poll conducted by the International Republican Institute, revealed that over 50 percent of Arab Iraqis identified most strongly with the Iraqi identity, while only 20 percent and 12 percent most strongly identified with their religion and ethnic group, respectively. In the same poll, only 28 percent of the Kurdish respondents identified most strongly with the Iraqi identity, while 37 percent most strongly identified with their ethnic group. (Note 3) However, in October 2004 a poll conducted by the State Department Office of Research, over 50 percent of Kurds identified as either equally Iraqi and Kurdish or primarily Iraqi and then Kurdish. (Note 4)

Therefore, Iraq remains a state without a nation, as almost no progress has been made towards fostering a sense of 'Iraqiness' among the country's divided ethnic and religious communities. The absence of any common attachment to the values, goals and symbols or any form of 'social glue' holding post-Saddam society together has serious implications for the consolidation of Iraqi statehood. (Note 5)

In such constellation of political events it is expected that Iraq will suffer from various forms of political instability such as sectarian violence, frequent demonstrations, strikes, and perhaps a civil war. By the fall of 2006, violence between Arab Sunnis and Shi' ites had dramatically increased. Between 110 and 130 people were killed every day in Iraq, and the vast majority were dying because of targeted sectarian attacks. (Note 6) All the ingredients for civil war existed in Iraq in 2003: Sunni Arabs were bitter at their ouster from positions of power and privileges, and fearful of the future; Shi'as insistent that Iraq will be ruled on their terms; an Arab Sunni belief that Shi'a are traitors bent not only on destroying the Iraq the Arab Sunnis had built, but also on handing the country over to a bitter national enemy; a Shi'a belief that many Sunni Arabs were unrepentant supporters of Saddam Hussein who would enthusiastically resume the killing of Shi'as if ever again given a chance at power. (Note 7) 
Factionalism among the Arab Sunnis and the Shiite approaches levels seen in Somalia, and multiple armed groups on both sides appear to believe that they could wrest control of the government if U.S. forces left. (Note 8) However, despite all of these, the government has been functioning, regular elections have been held and despite a very high corruption in all governmental institutions, economic performance has been quite satisfactory taking into consideration the fact that the country had gone through occupation and a very severe sectarian brutal conflict.

\section{The Iraqi Insurgencies}

Opposition to the Coalition presence started in the months following the invasion of Iraq, and particularly from May 2003, and can be roughly divided into two categories. The first, geographically located in the 'Sunni Triangle' between Baghdad and Mosul, was, and remains, composed mainly of Sunni Arabs but also had Kurds and Turkmens within its ranks. Indeed, there are several insurgencies ongoing within Iraq that are associated with the Sunni Arab community, whether ex-Ba'thist, neo-Ba'thist, Arab nationalist, home-grown Islamist or al-Qaeda-associated factions. (Note 9)

The second opposition category has its strongholds in Baghdad and the Shi' $i$ south, and is composed of radicalized Shi' is that have occasionally rebelled against the Iraqi government and the occupation forces.

As we have seen, SCIRI (Supreme Council for Islamic Revolution in Iraq) and Da'wa (Party of the Islamic Call) party assumed a prominent position early on following the fall of Baghdad. From being involved with the exiled Iraqi opposition movement, both parties were recognized as important actors by the US, and SCIRI also benefited from its close ties with the Iranian government. In addition to these political organizations, the Hawza al-Marja iiyya(Note 10) had emerged as a force capable of influencing popular sentiment, and Ayatollah al-Sistani came to the scene and he could act politically when he needed to.

There was, however, another force among the religiously minded Shi'i that did not fall under the control of SCIRI or $\mathrm{Da}^{\text {'wwa }}$ and viewed Ayatollah al-Sistani with a certain degree of suspicion. To understand this force, we need to go back to the late 1990s. Saddam had been having particular trouble with the most prominent Shi'i cleric, Grand Ayatollah Mohammed Sadiq al-Sadr and so ordered his assassination. Along with his two eldest sons, the marja 'was killed in a hail of bullets in Najaf in February 1999. (Note 11) Sadiq al-Sadr had been an immensely popular figure, and particularly among those youths who had been marginalized and dispossessed by the inequities of Saddam's regime. One concentration of the poorest of Shi' is in Iraq was in the rather inappropriately named Saddam City on the west bank of the Tigris next to Baghdad, where as many as two million people lived in appalling conditions. (Note 12) The killing of the Grand Ayatollah sparked off violent clashes between the followers of al-Sadr and Saddam's security forces. Hundreds died, but the fire of rebellion had been lit among these followers of Sadr, and would grow following Saddam's removal. In March 2003 Saddiq al-Sadr's surviving son Muqtada, emerged as the leader of the Sadr Movement(Note 13).

As the inheritor of a large and wealthy movement, Muqtada was well positioned to fill the administrative vacuum left behind by Saddam's defeat and Coalition mismanagement. Saddam City was quickly renamed Sadr City, and Muqtada and his movement organized local services, food distribution and security while the effect of Garner's actions remained unseen - indeed, it seemed that Muqtada's forces had expelled Iraqi forces from Sadr City before Saddam had even been defeated. As a figure who had stayed in Iraq and suffered under the dictatorship, Muqtada had little time for the returning exiled politicians and resolutely opposed the presence of foreign occupiers in his country. As a proud Iraqi nationalist, he

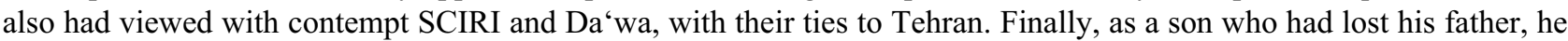
also was critical of his father's successor, Sistani, due to the latter's unwillingness to air his views and criticize the atrocities committed by Saddam. With so many grievances, and with such a large and devoted following, it would only be a matter of time before Muqtada came into conflict with those around him.

Muqtada's rise was totally unpredicted by the US and the Iraqi government. But his heightened influence in, and even control over, large parts of northern Baghdad, combined with his attempts to spread his message of radical Shi'ism and anti-occupation rhetoric to other areas of the country on the run-up to the 28 June handover of sovereignty, meant that neither the CPA (Coalition Provisional Authority) nor the IGC (Iraqi Governing Council) could ignore him. Believing him to be little more than a young cleric with an obvious ability to rabble-rouse, the CPA attempted to intimidate Muqtada into compliance. His newspaper, Al-Hawza, was closed down on 28 March and one of his deputies, Sheikh Mustafa al-Yacoubi, was arrested in Najaf. (Note 14)

Within days, the Sadr Movement was revolting across the south of Iraq and in Baghdad. Rather than following the Sunni Arab insurgents' tactics of guerrilla attacks, the Mahdi Army(Note 15) was more brazen in its approach and attempted to fight US forces in the open. The plan was always destined to face militarily, as there was no way that the Mahdi Army could hope to defeat such a superior military force. But the plan succeeded for Muqtada in a political sense. His taking refuge in the holy city of Najaf meant that the US could not attack him in case it provoked a wider-scale Shi' $i$ revolt, and Muqtada not only survived the fighting but also escaped arrest - in effect, he had stood up to the Americans. The Sadr Movement was weakened in the short term by picking a fight with the US military, but in the longer term its popularity 
was on the rise as new supporters saw Muqtada as the one leader who would not bow down to the authority of the occupiers.

While Muqtada was organizing his followers in the Sadr City, Sunni Arab insurgent movements were beginning to coalesce in the days following the demise of Saddam's regime. Several different trends emerged but each was unified in its opposition to the occupiers and, to a greater or lesser degree, the Shi' $\mathrm{i}$-dominated government.

The first of these groups was essentially the remnants of the deposed regime. As it became clear that the state had, for practical purpose, evaporated, and the Coalition had failed to replace it, the remnants of the deposed regime's security services, elite military outfits and paramilitary organizations regrouped. (Note 16) Initially, many of these insurgents did not take up arms against the Coalition forces. Rather, 'they wanted to see whether the Americans were going to be liberators or occupiers'. (Note 17) With the harder security line taken by the incoming CPA, many would soon see the occupying forces in the most possible light. Undoubtedly, with Bremer's demobilizing of the army, these groups benefited from the existence of stockpiles of weaponry across the country, and had access to the vast financial resources of the $\mathrm{Ba}$ 'th Party. Former regime supporters and ex-military figures recommenced fighting the Americans in particular, unified in their aim to defend Iraq against an external aggressor.

The second set of Sunni Arab insurgencies had its origin within Islamist group in Iraq itself. But, rather than there being one root, there were in effect two trends that came together: a 'regular' religious network of charities, mosques and organization, and influx of militants. With regard to the former category, Iraq, along with all other Middle East countries, had experienced an upsurge in the growth of Islamist sentiment. One of the established Islamist political organizations was the Iraqi Islamist Party (IIP) led by Muhsin Abd al-Hamid. The party's history can be traced back to 1960 but, due to the potential threat it posed to the military regimes of the period, it was effectively banned and only appeared publicly following Saddam's downfall. (Note 18) A further group that would achieve considerable notoriety was the Association of Muslim Scholars (AMS) led by Dr. Harith al-Dhari. Both the AMS and IIP focused initially upon social and charitable works - essentially providing vital services for their communities. But the invasion of Iraq by non-Muslim forces and its subsequent occupation provided the spark which ignited this sentiment into a volatile opposition movement.

The elements of the 'home-grown' Islamist insurgency can be traced to the Kurdish mountains towards the end of the 1990s. Following splits in the most prominent Kurdish Islamist movement, the Islamic Movement of Kurdistan, a new group emerged from them known as Ansar al-Islam (the partisan of Islam), dedicated to the overthrowing of the secular KDP (Kurdistan Democratic Party) -and PUK (Patriotic Union of Kurdistan) dominated Kurdistan Regional Governments. The destruction of their bases in the Khormal region of Kurdistan by US bombers in 2003 served to change the focus of Ansar from their provincial concerns towards fighting the occupiers. The survivors ventured south to join forces with like-minded insurgents who were coalescing around the AMS and, to a lesser extent, the IIP. Together, these disparate groups formed the Jaish Ansar al-Sunna (Partisans of the Sunna Army). Other groups that managed to blend radical Islamism with nationalist sentiment also appeared, including the al-Jaish Islami fil-Iraq (Islamic Army in Iraq), which merged salafi discourse with patriotic ideals, perhaps indicating the involvement of former regime elements.

In addition to a home-grown set of Islamist insurgencies, the presence of US forces in Iraq and the lack of a state apparatus acted as a magnet for foreign fighter, commonly assumed to be members of al-Qaeda, travelling in from neighboring countries. The main 'foreign' insurgency group was dominated by the late Abu Musab al-Zarqawi and was called Tandhim al-Qaeda fi Bilad al-Rafidain (Al-Qaeda's Organization in the Land of the Two Rivers), formerly known as Al-Tawhid wal-Jihad (Monotheism and Jihad). This group gained infamy for undertaking the kidnapping and execution of Western contract workers, and was also blamed for suicide bombing attacks against Shi'i targets, particularly from 2004 onwards.

The reputation of this group would suggest that it remains the main opposition force in Iraq and it is primarily responsible for the majority of attacks that have taken place - and continue to take place - against Coalition forces and Iraqi government offices and individuals. This, however, would seem to be inaccurate and is perhaps a product of the focus placed upon this group by the US administration. Keen, indeed desperate, to show that Iraqis welcomed the Coalition as liberators, the US in fact benefited from the existence of a foreign Al-Qaeda-associated group, as it allowed blame for attacks to be attributed to 'non-Iraqis'. It would seem, however, that while Al-Zarqawi's group, even following his killing in June 2006, is powerful and effective, it is but one of many. Rather than being the core of the insurgency, the foreign element remains a small but deadly sideshow, with the most important component of the insurgency being indigenous Iraqi in origin.

The focus of the activities of the Sunni Arab insurgencies remained resolutely in the Sunni Triangle, until 2005. For the Coalition, there existed several troublesome towns and regions in the Triangle, including Ramadi, Balad, and Tikrit. However, it would be the town of Fallujah that would become the focal point of the world's media in 2004. After initially being relatively quiet town following Saddam's removal, confrontations between insurgents in Fallujah and US forces reached a climax with the killing and dismemberment of four contract workers in March 2004. Their particularly gruesome killing, and the broadcasting of pictures by the world's media, would see Fallujah made an example of by the 
US military. But, after a month-long military assault, US forces could still not enter the city. It was only after a siege that US Marines entered Fallujah in November, claiming to kill as many as 100 insurgents, but, in reality, much of this number was more likely to have consisted of innocent civilians.

With Muqtada al-Sadr's followers already rising against US forces, the US military and CPA were faced with a perilous situation. Rather than seek the support of the IGC, which was already seen as ineffectual by the CPA due to the inability of representatives to find common agreement on issues of importance, it seems that the decision to invade Fallujah, and to attack Muqtada's forces in southern Iraq, was taken unilaterally by the US. (Note 19) By doing so, the US pushed those Iraqis still uncommitted to the insurgency into joining their countrymen in their struggle to expel what was now seen as a dangerous and brutal occupier. The insurgency spread rapidly across Al-Anbar governorate, and Fallujah became a symbol of the resistance to the continued foreign presence and, in the wider Arab and Islamic world, evidence of the level of brutality to which the US military would go in order to force its vision on the new Iraq down the barrel of a gun.

\section{Political and Institutional Stability in Iraq}

More than six years have now passed since the American invasion of Iraq and overthrow of Saddam Hussein, and what is most notable is how little has changed for the better and how much for the worse.

For the past six years the country has held series of regular elections, two for representatives of the National Assembly and the third a referendum on the newly drafted constitution. (Note 20) The elections of 2005 brought to power a government which could stay in power until now. Despite withdrawal of some parties from the coalition in some stages and coming back, there was no change of regime using violent means such as assassination, coups d'état, revolution, etc. Along this line there was no any structural change in the political system of the country from democratically elected regimes to dictatorship, authoritarianism or military government. Government representatives through the policies that they made and laws which they passed were able to maintain the belief that the present and existing political institutions are the best possible ones at the moment.

It can be said that since the fall of Saddam, the political progress being made by the domestic political elites has been slow and, Iraq does seem to have been stagnating. In spite of the fact that many reforms have been adopted in such areas as defense, the judicial system, public administration, yet, state-level structures such as council of ministers and parliament have remained so weak that most important decisions could not be reached by political representatives. The identity factor is evident in all areas of public life and the real reintegration of society is yet to begin. Inability to reach consensus on any major social issue has disappointed the public and affected the overall sense of political and institutional stability.

The poll by the BBC, ABC, ARD and NHK of more than 2,000 people suggests that a majority believe that security in their area has improved since 2007. (Note 21) And while most Iraqis still believe US troops are making things worse, the numbers who want the Americans to pull out immediately has fallen. But the poll also shows Iraq's main ethnic groups are deeply divided. While $55 \%$ of all Iraqis believe that their lives are good, only $33 \%$ of Arab Sunnis are happy with their lives, compared with $62 \%$ of Shias and $73 \%$ of Kurds. "In spite of all the improvements, the Arab Sunni population of Iraq clearly remains deeply alienated, and deeply hostile," the survey shows that Some $62 \%$ of those polled say security in their own area is good - up from $43 \%$ last year - but exactly half of all Iraqis still rate security as the biggest problem for the country overall. And Iraqis are still reporting problems with the provision of basic services. The poll also suggests that Iraqis are skeptical about political progress. Only $21 \%$ believe that the increase in US forces has made conditions for political dialogue in Iraq better, while $43 \%$ think the surge has made conditions worse. And 38\% want American forces to leave immediately, compared with $35 \%$ who want the troops to remain until security has been restored. (Note 22 )

The survey suggests that support for the Iraqi government is returning, after a drop-off in recent years. Just under $50 \%$ of Iraqis now have confidence in the government, up from 39\% in March 2007. Overwhelming numbers of both Arab Sunnis and the Shias still want Iraq to remain a unified nation. By comparison the Kurds are the splitters. Only $10 \%$ of them want to keep the country together. Support for Iraqi security forces remains high, with $67 \%$ expressing confidence in the police and $65 \%$ in the army. In contrast, public confidence in local militias has fallen since last year. In March 2007 it stood at $36 \%$, by August it was down to $24 \%$, and it has fallen another $2 \%$ since then, to $22 \%$. Within that, Shia feelings about local militias have fallen the most steeply. In March 2007, 51\% of Shias had confidence in militias - now that figure has declined to $28 \%$, the survey suggests. The poll is the fifth survey to be conducted since the beginning of the US-led invasion in 2003. (Note 23)

Since politicians tend to play by identity card, conflict between them has taken on an element of ethnic and religious disagreement. Therefore, any issue not being resolved using negotiation and consensus would eventually lead and result in a political crisis based on ethnic differentiation within the political elite. Unity behind ethnic and religious lines, disregarding political differences per se, has been very evident. This has had to negative impact on the relations among various Iraqi groups more generally and has contributed to a growing sense of insecurity and distrust. Therefore, it can be claimed that inter-ethnic instability in the country has to be primarily related to the political crises in the country which take place in a context of ethnicity. 
Today, given the serious difficulty experienced in formulating political solutions in the post-Saddam Iraq supports the fact that change of the present system depends on achieving domestic consensus which has been lacking for the past six years.

The political system of Iraq suffers from a lack of consensus among the political elites that represent the three dominant ethnic groups and is kept stable only by the massive presence of the US forces in the country. Hence, despite considerable progress that has been achieved in the past few years, a complete withdrawal of US forces from Iraq would threaten the survival of the system and the state. The lack of the elite accommodation and the effect of elite confrontation are revealed in an extremely high level of distrust among the political elites and continuous imposition of laws by the international community due to inability of domestic political actors to reach consensus on almost all those issues pertaining to the state institutions.

\section{Economic Performance in the Post-Saddam Era}

By 2003, after two wars, many years of sanctions and increasing economic autonomy of Kurdistan, Iraq's economy was highly fragmented and there was little in the way of a national macroeconomic policy. Two wars and more than a decade of sanctions did not lead to reform or internal collapse. By 2003, however, Iraq's economy was severely weakened in every area; foreign reserves were depleted, development planning had virtually ceased, the infrastructure was severely damaged and a vast majority of the population was impoverished. (Note 24) In spite of the shattered economy and the weak institutional organization, the Iraqi regime as a state could function and could provide the basic service to the population prior to the invasion. However, after the fall of Saddam's regime, the Iraqi state collapsed, its power structures disintegrated and there was nothing to replace them. Basic services were halted, and the looting which followed sparked no bank, hospital, power station or government office. It was estimated that the cost to the economy was $\$ 12$ billion. (Note 25)

The CPA, under Ambassador L. Paul Bremer III, issued within a week of his arrival in Baghdad the decree of de-Ba'thification. Overnight almost 30,000 Iraqis- including middle management in economic ministers, teachers and doctors- were dismissed from their jobs. (Note 26) The senior management of the country either been arrested or fled the country and middle management were kicked out. The result was a huge vacuum which the Americans could not fill. Meanwhile, the CPA was dealing with one crisis after another (political and economic) and was trying to cope with a damaged economy plagued by price distortions and inefficiencies. The Americans were under pressure to show progress. This led to an emphasis on headline projects to deliver the basic services such as (oil, electricity, and clean water to the population, while long-term projects to improve agriculture and industry were pushed aside. (Note 27) Although U.S. Congress had allocated, by the end of 2005 , aid totaling about $\$ 21$ billion, more than a third remained unspent. In fact, the failure to spend Iraq's reconstruction money, particularly in the first year of war, was a contributing factor to the increased violence and high unemployment. (Note 28)

Since the CPA was dissolved on 28 June 2004, 'militias appear to have carried out or co-opted their own areas of economic control and regulations'. (Note 29) Corruption and trade in smuggled oil became the cornerstones of the new economy of Iraq. It is essential to look at Iraq's economy and its major problems. The first economic issue facing Iraq is inflation, a recurrent problem for Iraq. As a result of the invasion of Kuwait and the subsequent sanctions, hyperinflation became a structural problem. (Note 30)

After the collapse of Saddam's regime, inflation stabilized at around 32 percent to 34 percent per annum. However, in late 2005 inflation began to rise sharply due to increased violence, the fallout from the state control, corruption, increasing wages increasing cost of house rentals and the rise of fuel price. (Note 31) By January 2007, inflation reached 66.5 percent reflecting shortages of key commodities, primarily fuel. (Note 32) Following an intensified policy effort by the Iraqi government to bring inflation under control, the annual inflation rate declined to 38 percent in May 2007(Note 33), and to 15 percent by the end of that year. (Note 34) The Iraqi Central Bank has played an important role in combating inflation, and in fact, the establishment of a relatively independent Central Bank has been one of the achievements in post-war Iraq. By raising interest rates, the Central Bank forced the Iraqi dinar (ID) exchange rates to appreciate, thus reducing the imported inflation. (Note 35) The ID which, after its introduction in 2004, initially traded at around 1,450 to US dollar, reached 1,225 to the US dollar by the end of 2007, and further strengthened to 1,196 to the US dollar in June 2008 with the increase in oil prices. (Note 36)

The second issue facing Iraq from an economic point of view, and which had more severe consequences on Iraq's economy, was unemployment. Estimates for unemployment range from 25 percent to 40 percent, which even at the lower rate is socially and economically destabilizing. (Note 37) A UNDP survey in 2004 indicated that the labor force participation rate in Iraq is 40.9 percent, which was comparable to that in neighboring countries of 37 percent to 43 percent (Iran, Jordan), while Syria had a somewhat higher activity level of 53 percent. The main reason for the low participation rate is that most women are not economically active. (Note 38) The table below shows the rates of nationwide unemployment. The estimates of Iraq's unemployment rate vary, but as the table 1 indicates, unemployment rates varied between $25-40 \%$.The CPA has referred to a $25 \%$ unemployment rate, the Iraqi Ministry of Planning mentioned a $30 \%$ unemployment rate, whereas the Iraqi Ministry of Social Affairs claims it to be $48 \%$. There is an 
inherent difficulty in measuring the Iraqi rate of unemployment over time. Considering the increase in entrepreneurial activity after the end of the war, we have for the purposes of this database assumed that there has been an improvement in unemployment levels, and hence weighted information supporting such a conclusion heavier than contradictory data reports.

The dissolution by Bremer of the Iraqi army which had employed between 400,000 and 500,000 people (estimated at 7 percent of the labor force), coupled with de-Ba'thification, added something like 8 percent to 10 percent to unemployment, especially among the Arab Sunnis. (Note 39) The Bremer's decisions proved to be costly mistakes. The point is not that these two institutions should have been allowed to carry on their business as usual. The consequential error lay in the timing. Looking over the horizon instead of just down the road, Bremer and the CPA forgot to ask themselves what might mean to turn thousands of military officers loose on the streets without even the promise of monetary compensation. (Note 40) Similarly, to proscribe all Ba'thists without exception from taking part in reconstruction was to exclude most of the very Iraqi professionals whose service will have proved crucial in rebuilding the country. (Note 41) Given the ideological decay that permeated the ranks of the Party in the late 1990s, the bulk of the Party's rank and file were nominal members at best, whose Party card simply meant better job prospects.

It would have been wiser for the CPA to have begun with wide-ranging investigations aimed at identifying human rights violators and active Saddamists among Party members and military officers before dismissing them without imbursement. (Note 42) Therefore, the combination of high inflation and unemployment as one member of Iraqi Council of Representatives said: (Inflation and unemployment led to a severe increase in poverty, forcing people to engage in murky business to make a quick buck (crime, arms sales and prostitution are all dramatically on the increase), and corruption became the norm in every facet of life). (Note 43) Other Iraqi officials considered the unemployment in Iraq as time bomb and that the major reason for its spread is the 'impairment to the economic basis' of the country following the invasion. (Note 44) Whatever, the reasons and however strong the efforts were to resolve this crisis, the result was poor. Even three years after the UNDP survey, a poll by an independent opinion research company of 2,000 Iraqis across all 18 provinces clearly indicated that the quality of life in Iraq has further deteriorated in 2005 and 2006. More than three-quarters of respondents to the poll said that jobs were hard to find and that the availability of clean water, medical care and basic goods and services have, after some improvement in 2005, all deteriorated. (Note 45)

\section{Corruption in Iraq}

Corruption was already prevalent during Saddam's regime but the Oil-for-Food program which accompanied the sanctions in the 1990s almost institutionalized corruption. Different estimates of illicit Iraqi income from surcharges on oil sales ranged from $\$ 300$ million to $\$ 7.5$ billion. Saddam created a true patronage and reward system not only internally but also with foreign companies and influential individuals outside Iraq. (Note 46) Unfortunately, corruption and patronage system continued after the 2003 invasion. Philippe Le Billion describes dramatic transitions similar to what happened after the fall of Saddam (political and economic transitions are particularly prone to corruption and transitions in conflict-affected area are not exception. Corruption is often one of the key concerns of local population in conflict-affected areas during reconstruction, along with insecurity and unemployment). (Note 47)

Indeed, this general description fits Iraq: transition, reconstruction, insecurity and high unemployment. Ali Allawi, who served in the Iraqi government from the end of 2003 to mid 2006, described the explosion in corruption that took place in different ministries and the shocking methods of embezzlement by so many ministers and senior officials. (Note 48) He briefly described the country and its bureaucracy following the invasion: (the Iraqi state combined the worst features of a centralized bureaucracy with vestiges of the occupation, and a near collapse of the information, reporting and control mechanisms that underpin any functioning government authority. The legacy of corrupt practices, outdated management systems, incompetence and nepotism was neither seriously challenged nor bypassed). (Note 49)

One of the characteristic of Iraq's corruption is that insurgents, smugglers and corrupt officials collaborate at different levels, weaving an intricate web that makes it difficult to distinguish among them. The US embassy in Baghdad has argued that the Iraqi government 'is not capable of even rudimentary enforcement of anti-corruption laws' and the prime minister's office is openly hostile to the idea of an independent anti-corruption agency. (Note 50) A report by the Brookings Institution affirmed that 'corruption is probably the single greatest factor inhibiting the creation of a credible Iraqi political institution. Like the problem of insecurity, with which it is intertwined, corruption undermines nearly every aspect of reconstruction.'(Note 51)

One-third and possibly more, of the fuel from Iraq's largest refinery in Bayji, 208 kilometers (130 miles) north of Baghdad, on the main road to Mosul and in a Sunni Arab-dominated region, is diverted to the black market. 'Tankers are hijacked, drivers are bribed, papers are forged and meters are manipulated' (Note 52) to finance the insurgency, pay corrupt officials and reward the smugglers. Gas stations are often built to get fuel at subsidized government rates to be resold later onto black market at higher price. 
Estimates for smuggling range from \$2.5 billion per year, (Note 53) and there are indications that 100,000 barrels of oil are being smuggled from Iraq on a daily basis. (Note 54) With oil prices reaching more than $\$ 130$ a barrel, Iraq's oil revenues in 2008 could have reached $\$ 60$ billion.

Thus corruption has dominated Iraq's economy, but this is, unfortunately, not limited to the central and southern governorates of Iraq. Kurdistan, which has enjoyed relative stability and safety and whose economy has prospered, is also suffering from wastefulness and corruption. Again, and in spite of lack of violence, cronyism and corruption have become integral to Kurdistan's economy.

Kurdistan, with population of about four million, has become an oasis in violent Iraq and enjoying an economic boom. It has two international airports (Arbil and Sulaimanya) and five universities operating in the area, which received many displaced academic and professionals from central and southern Iraq. The Kurdish government has promulgated a liberal investment law allowing foreign investors to own 100 per cent of the investment project capital, while giving them a ten-year tax holiday and a five-year exemption from customs and duties on the import. (Note 55)

However, Kurdistan's economy is also suffering from unemployment and inflation. School and university graduates competed for jobs in the government ministries and one report suggested that excess positions are created in the public sector, in order to reduce unemployment and provide jobs to these young people. (Note 56) Meanwhile, due to the construction boom, Asian and African labor is imported to do the manual work. (Note 57) Despite the flourishing of economy, the ordinary Kurds, who do not belong to any Kurdish political parties, are struggling to survive, while state money gets siphoned off into private pockets.'(Note 58)

Two families control the political and economic activity of Kurdistan. The Kurdish Democratic Party (KDP), which controls Erbil and surrounding cities, is headed by Masoud Barzani, while the Patriotic Union of Kurdistan (PUK), which controls Sulaimanya and surrounding areas, is headed by Iraq's President, Jalal Talabani. Each party has its local government but more importantly each has its own economic arm. (Note 59) The Zagros group of companies is the KDP's economic arm in Erbil, and the Nokan group is the PUK's economic arm in Sulaimanya. These two families have direct control over, and involvement in, their two respective companies. Every member of the two families has a senior job either in the government, the security services or economic conglomerates which they control, while they are depriving the ordinary people. (Note 60)

Kurdistan sits on large oil reserves, explored and unexplored, and while there is still dispute between the Kurdistan and Baghdad governments about an oil law that would define Kurdistan's oil rights and resolve the conflicting interests among the Kurds, Shi'a and Arab Sunni, the Kurds receive 17 per cent of Iraq's oil revenues (in 2007 estimated to have been \$6.1 billion) from the central government. (Note 61)

The lack of transparency is remarkable. The budget of the Kurdish government based on the allocation from Baghdad is divided between the two parties-52 per cent to KDP and 48 per cent to PUK- but no fiscal data are published by the Kurdish Regional government. Amer of AL-Jama' Islamyia,(Head of Jama' Islamyia) Mr. Ali Baper, expressed his disappointment with the current Kurdish regional government, he said ( The two leading parties in power have been running the country without any accountability and bookkeeping. This is a grave failure with serious implications and raises questions as to why there were not any records available for the last few years. The first thing that comes to mind when looking at the status quo is abuse of power and corruption) (Note 62).

In spite of the corruption, cronyism, and nepotism, there were some achievements in Iraq's economy. The question is, can these achievements pave the way in the future for a new economy with plentiful opportunities for the Iraqi people?

Setting up an independent central bank and issuing the new currency were both success stories in Iraq's economic management in the post-Saddam era. Reducing the external debt was another. In 2004, Iraq's external debt stood at about $\$ 132$ billion to countries and commercial creditors worldwide, but by 2008 , the country's debt had dropped to about $\$ 33$ billion. (Note 63) It is interesting to note that Saudi Arabia and Kuwait, countries that benefited from the toppling of Saddam, refused to reduce or forgive the debt.

A senior Kurdish leader Dr. Mahmoud Othman during my interview with him, explained to me that the main reason for lack of progress, apart from violence, is that many Iraqi economic managers post-2003 are not equipped to run large concerns as they lack the ability to plan on a long-term basis; their focus is on short-term gains. He assured me, however, that Iraq is rich and everything has to change, change towards better, just like in post-war Germany and Japan. (Note 64)

\section{Conclusion}

The question is whether democracy is possible in Iraq? Or should the United States divide Iraq along ethnic or sectarian lines? There has been some progress on the democratization front. A series of elections have been held. Although it can be said that conducting largely free and fair elections is not sufficient evidence of democratization, however, it is necessary component of the process. 
To explain the evolution of violent instability in the wake of regime change, the collapse of the state is of much greater significance than the supposedly trans-historical existence of communal antipathies or indeed the ineptitude of Iraq's new ruling elite. The entrance of US troops into Baghdad in the first weeks of April 2003 resulted in the death of the Iraqi state. Faced with the widespread lawlessness that is common after violent regime change, the US did not have the numbers of troops needed to control the situation. After three weeks of violence and looting the state's administrative capacity was destroyed. Seventeen of Baghdad's twenty-three ministry buildings were completely gutted.

Iraq today finds itself in a situation of state failure. Against this background instability is driven by two interlinked problems, which have caused the profound insecurity and violence that now dominates the country.

The complete collapse of state capacity and the US disbanding of the Iraqi army resulted in an acute security vacuum. This was seized upon by a myriad of groups deploying violence for their own gain. Organized crime became a dominant source of insecurity for ordinary Iraqis. For coalition and Iraqi security forces, it is the diffuse groups fighting the insurgency in the name of Iraqi nationalism, increasingly fused with a militant Islamism, that have caused the highest loss of life. But in early 2006, a new crisis arose with even greater potential for destabilization: civil war. The explosion that destroyed the al Askariyya Mosque in the Iraqi city of Samarra, on February 22 2006, marked a watershed, exacerbating already mounting sectarian violence and the resultant population transfers.

The second problem that has dominated the politics of the country since the fall of Saddam Hussein, is the question who should rule? How to find Iraqis who after thirty-five years of dictatorship have both the technical capacity and national legitimacy to rule over a country of 26 million people? 2005 was dominated by the struggle to build a representative government that could act as a rallying point for the country; allowing the population to invest hope and legitimacy in a new ruling elite that could stabilize the nation and move towards rebuilding the state. For Iraq to stabilize and regime change to be a success, sustained progress will have to be made in two areas, the building of countrywide state capacity and the growth of a legitimate and competent governing elite. Although economic recovery in Iraq has not yet met expectations, there have been positive developments worth noting. Thus, during its transitional period, the country has progressively moved from dependence upon US and International aids to a process of economic development. Iraq has begun to develop a legal and regulatory framework that may eventually promote a free market economy.

\section{References}

Adeed Dawisha \& Larry Diamond, "Iraq's Year of Voting Dangerously," Journal of Democracy 17, no.2(2006):89-103

Adeed Dawisha. (2009). Iraq: A Political History from Independence to Occupation, Princeton University Press, p262.

Ahmed, S.Hashim. (2006). Insurgency and Counter-Insurgency in Iraq, Hurst \& Co.Ltd, p.19.

Ali A. Allawi. (2007). The Occupation of Iraq: Winning the War, Losing the Peace, New Haven, Yale University Press, pp.353-369.

Alnasrawi , Ali. (2002). Iraq's Burdens: Oil, Sanctions and Underdevelopment, Connecticut, Greenwood Press, P.104.

Alnasrawi, Abbas. (2002). 'Long term Consequences of Wars and Sanctions', in Mahdi, Kamil A. (ed.), Iraq's Economic Predicament, Reading, Ithaca Press, pp.343-348.

Anthony H. Cordesman. (2006). Iraq's Insurgency and the Road to Civil Conflict; Ahmed S. Hashim, Insurgency and Counter-Insurgency in Iraq, Hurst \& Company: London.

Billion, Philippe Le. (2005). 'Corruption, Reconstruction and Oil Governance in Iraq', Third World Quarterly, 26//4-5, p.689.

Bremer L.Paul III. (2006). My Year in Iraq: The Struggle to Build a Future of Hope, Simon \& Schuster, pp.117-222.

CNN. (2007). 'Draft report: Iraq government "not capable" of fighting corruption', 27 September. www.cnn.com.

Cole, Juan. (2003). 'The United States and ShiNite Religious Factions in Post-Ba'thist Iraq' , Middle East Journal, vol.57, no.4, pp.543-566.

Dodge, Toby. Iraq's Future: The Aftermath of Regime Change, Adelphi Paper372, London: International Institute for Strategic Studies, p.10.

Etherington, Mark. (2005). Revolt on the Tigris: The Al-Sadr Uprising and the Governing of Iraq. London: Hurst \& Co, p.168.

Galbraith. W. Peter. (2006). The End of Iraq: How American Incompetence Created a War without End, Simon \& Schuster: New York, p.175

Glantz, James and Worth, Robert F. (2006). "Attacks on Iraq Oil Industry Aid Vast Smuggling Scheme', The New York Times, 4 June.

http://news.bbc.co.uk/2/hi/middle_east/7300115.stm. 
http://www.iamb.info.

http://www.imf.org/external/pubs/ft/scr/2007/cr07301.pdf.

http://www.iraqdirectory.com.

IMF. (2007). Iraq: Country Report No.07/301, August.

James D. Fearon. (2007). Iraq's Civil War, Foreign Affairs, March/April, 2-15.

Lando, Ben. (2006). 'Analysis: Iraq's Oil Smuggling,' Parts I and II, United Press International, quoted in Iraq Update, 15 December.

Lijphart, Arend. (1968, April). "Typologies of Democratic Systems" Comparative Political Studies, Vol.1, No1.

Lijphart, Arend. (1968). The Politics of Accommodation: Pluralism and Democracy in the Netherlands, Berkeley: University of California Press.

Marr, Phebe. Iraq's Identity Crisis, in Iraq: Preventing Another Generation of Conflict, Malone, M., David, Rowswell, Ben, \& Bouillon, Markus. (2007). Lynne Rienner Publisher, P.54.

Napoleoni, Loretta. (2005). Insurgent Iraq: Al Zarqawi and the New Generation, Constable, London, p.136.

Oppel, Richard A. (2008). ' Iraq Insurgency Runs on Stolen Oil Profits', The New York Times, 16 March.

Owen, Roger. (2007). 'Reconstructing the performance of the Iraqi economy 1950-2006: an essay with some hypotheses and many questions', international Journal of Contemporary Iraqi Studies 1/1, pp.93-101.

Packer, George. (2005). The Assassin's Gate, New York, Farrar, Straus and Giroux, P. 139.

Parker, Christopher and Moor, Pete W. (2007). 'The War Economy of Iraq', Middle East Report, no.243 (Summer), P.13. Phillips, David L. (2005). Losing Iraq, New York, Westview Press, pp.143-153.

Pollack, Kenneth M. (2006). A Switch in time: A new Strategy for America in Iraq, Saban Centre for Middle East Policy at the Brookings Institution, February, p.XIII.

Sassoon, Joseph. (2009). The Iraqi Refugees: The New Crisis in the Middle East, London. New York, I.B.Tauris, P.131. Survey of Iraqi public opinion. (2005). International Republican Institute, February 27, March 5.

The Brookings Institution, Iraq Index, www.brookings.edu/iraqindex

UNDP/ Ministry of Planning and Development Cooperation, Iraq Living Conditions Survey 2004, vol.II, Analytical Report, P.120, Baghdad, 2005.

www.acepilots.com/unscam/.

www.brookings.edu/saban/iraq-index.aspx.

\section{Notes}

Note 1. Arend Lijphart, "Typologies of Democratic Systems, Comparative Political Studies, Vo1,1, No,1, p.8.

Note 2. Lijphart, The Politics of Accommodation, pluralism and Democracy in the Netherland, Berkeley: University of California Press 1968, p.71.

Note 3. Survey of Iraqi public opinion, International Republican Institute, March 2005.

Note 4. Marr, Phebe, Iraq's Identity Crisis, in Iraq: Preventing a New Generation of Conflict,P.54.

Note 5. Interview with Iyad Samara'i.

Note 6. Adeed Dawisha, Iraq: A Political History from Independence to Occupation, P.262.

Note 7. Galbraith. W. Peter, The End Of Iraq: How American Incompetence Created a War Without End, Simon \& Schuster: New York, 2006, p.175.

Note 8. James D. Fearon, Iraq's Civil War, "Foreign Affairs, March/April, (2007), p.3.

Note 9. See, Anthony H. Cordesman, Iraq's Insurgency and the Road to Civil Conflict; Ahmed S. Hashim, Insurgency and Counter-Insurgency in Iraq, Hurst \& Company: London, 2006.

Note 10. More fully, hawza al-marja'iyya. The religious establishment surrounding the leading clerical figures of Shi'ism.

Note 11.Cole, Juan (2003) 'The United States and ShiNite Religious Factions in Post-Ba'thist Iraq', Middle East Journal, vol.57, no.4, pp.543-566.

Note 12.Napoleoni, Loretta, Insurgent Iraq: Al Zarqawi and the New Generation, Constable, London,2005, p.136. 
Note 13.Movement of Muqtada al-Sadr. Powerful force in post-2003 Iraq.

Note 14.Etherington, Mark ,Revolt on the Tigris: The Al-Sadr Uprising and the Governing of Iraq. London: Hurst \& Co, 2005, p.168.

Note 15.Militia of Movement of Muqtada al-Sadr.

Note 16.Dodge, Toby, Iraq's Future: The Aftermath of Regime Change, Adelphi Paper372, London: International Institute for Strategic Studies, p.10.

Note 17. Hashim Ahmed, Insurgency and Counter-Insurgency in Iraq, p.19

Note 18.Ibid, p.21.

Note 19. See My year in Iraq, pp.217-222.

Note 20. Adeed Dawisha \& Larry Diamond, "Iraq's Year of Voting Dangerously,"89-103.

Note 21.The survey was conducted by D3 Systems and KA Research Ltd for the BBC, ABC News, NHK of Japan and RAD of Germany. See http://news.bbc.co.uk/2/hi/middle_east/7300115.stm.

Note 22.Ibid.

Note 23.Ibid.

Note 23.Alnasrawi, Abbas, 'Long term Consequences of Wars and Sanctions', in Mahdi, Kamil A. (ed.), Iraq's Economic Predicament, Reading, Ithaca Press, 2002, pp.343-348.

Note 25.Packer, George, The Assassin's Gate, New York, Farrar, Straus and Giroux, 2005, P. 139.

Note 26.Phillips, David L., Losing Iraq, New York, Westview Press, 2005, pp.143-153.

Note 27.Owen, Roger, 'Reconstructing the performance of the Iraqi economy 1950-2006: an essay with some hypotheses and many questions', international Journal of Contemporary Iraqi Studies 1/1 (2007), pp.93-101.

Note 28.International Advisory and Monitoring Board (IAMB) of the Development Fund for Iraq (DFI), Report for period 22 May 2003 to 28 June 2004. The IAMB was established by the United Nations as an independent oversight body for the DFI to ensure that Iraq's oil export sales were made consistent with international best practice. http://www.iamb.info.

Note 29.Parker, Christopher and Moor, Pete W., 'The War Economy of Iraq', Middle East Report, no.243 (Summer 2007), P.13.

Note 30. Alnasrawi, Ali, Iraq's Burdens: Oil, Sanctions and Underdevelopment, Connecticut, Greenwood Press, 2002, P.104.

Note 31. Sassoon, Joseph, The Iraqi Refugees: The New Crisis in the Middle East, London. New York, I.B.Tauris, 2009, P.131.

Note 32.Ibid.

Note 33.International Monetary Fund, Iraq: 2007 Article IV Consultation, Fifth Review Under the Stand-By Agreement, Staff Report; Public Information and Press Release on the Executive Board Discussion; and Statement by the Executive Director for Iraq, IMF Country Report no. 07/301, August 2007. http://www.imf.org/external/pubs/ft/scr/2007/cr07301.pdf.

Note 34.Iraq Directory, 2 January 2008. http://www.iraqdirectory.com.

Note 35.Sassoon, Joseph, The Iraqi Refuges, P.131.

Note 36.Ibid.

Note 37.The Brookings Institution, Iraq Index, 31 March 2008. www.brookings.edu/saban/iraq-index.aspx.

Note 38. UNDP/ Ministry of Planning and Development Cooperation, Iraq Living Conditions Survey 2004, vol.II, Analytical Report, P.120, Baghdad, 2005.

Note 39.Sassoon, The Iraqi Refugees, P.132.

Note 40.Adeed Dawisha, Iraq: A political History from Independence to Occupation, P.244.

Note 41. Ibid.

Note 42. Ibid, P.245.

Note 43.Interview with Dr. Mahmoud Othman, on 11-8-2008, Salahadin, Erbil, Iraqi Kuridtan.

Note 44. Interview with Dr. Humam Hamoudi, on 30-7-2008, Baghdad, Iraq. 
Note 45. IMF, Iraq: Country Report No.07/301, August 2007.

Note 46. A list of 270 names is published in a website called: Friends of Saddam-Al-Mada list of 270. See www.acepilots.com/unscam/.

Note 47. Billion, Philippe Le, 'Corruption, Reconstruction and Oil Governance in Iraq', Third World Quarterly, 26//4-5(2005), p.689.

Note 48. Ali A. Allawi, The Occupation of Iraq: Winning the War, Losing the Peace, New Haven, Yale University Press 2007, pp.353-369.

Note 49. Ibid, p.349.

Note 50. CNN, 'Draft report: Iraq government "not capable" of fighting corruption',27 September 2007. www.cnn.com.

Note 51. Pollack, Kenneth M., A Switch in time: A new Strategy for America in Iraq, Saban Centre for Middle East Policy at the Brookings Institution, February 2006, p.XIII.

Note 52. Oppel, Richard A.,' Iraq Insurgency Runs on Stolen Oil Profits', The New York Times, 16 March 2008.

Note 53. Glantz, James and Worth, Robert F., "Attacks on Iraq Oil Industry Aid Vast Smuggling Scheme', The New York Times, 4 June 2006.

Note 54. Lando, Ben, 'Analysis: Iraq's Oil Smuggling,' Parts I and II, United Press International, quoted in Iraq Update, 15 December 2006.

Note 55. Written response by Mr.Ihasan Abdullah, on October 7,2008. Mr. Ihsan is a member of Parliament of Kurdish Regional Authority.

Note 56. Interview with Dr. Kamal Kerkuki, on August 24,2008. Dr. Kamal is a Vice President of Kurdistan Parliament.

Note 57. Ibid.

Note 58. Interview with Muhammad Haji Mahmud, on August 17, 2008, Sulaimanya, Iraq.

Note 59. Although there was a unification of ministries between the two parties, each party still has its independent ministries: finance, Militia (Peshmerga), and the interior.

Note 60. Interview with Mr. Muhammad Haji Mahmud.

Note 61. Interview with Mr.Omar Hussein Ali, on October 2, 2008, Duhok, Iraq.

Note 62. Interview with Ali Baper, on August 12, 2008, Erbil, Iraq.

Note 63. IMF, Iraq: Country Report, August 2007

Note 64. Interview with Dr. Mahmoud Othman, on August 11, 2008, Erbil, Iraq.

\section{Interviews:}

1. Interview with Dr. Kamal Kerkuki, on August 24,2008. Dr. Kamal is a Vice President of Kurdistan Parliament.

2. Interview with Muhammad Haji Mahmud, on August 17, 2008, Sulaimanya, Iraq.

3. Interview with Mr.Omar Hussein Ali, on October 2, 2008, Duhok, Iraq.

4. Interview with Ali Baper, on August 12, 2008, Erbil, Iraq.

5. Interview with Dr. Humam Hamoudi, on 30-7-2008, Baghdad, Iraq.

6. Interview with Dr. Mahmoud Othman, on 11-8-2008, Salahadin, Erbil, Iraqi Kuridtan.

7. Interview with Iyad Samara'i. Mr Iyad is a speaker of Iraqi Parliament.

8. Written response by Mr.Ihasan Abdullah, on October 7,2008. Mr. Ihsan is a member of Parliament of Kurdish Regional Authority. 
Table 1. Nationwide Unemployment Rate Since May, 2003

\begin{tabular}{|c|c|}
\hline Month & Unemployment Rate Nation-wide \\
\hline May 2003 & N/A \\
\hline June & $50-60 \%$ \\
\hline July & N/A \\
\hline August & $50-60 \%$ \\
\hline September & $\mathrm{N} / \mathrm{A}$ \\
\hline October & $40-50 \%$ \\
\hline November & $\mathrm{N} / \mathrm{A}$ \\
\hline December & $45-55 \%$ \\
\hline January 2004 & $30-45 \%$ \\
\hline February & $30-45 \%$ \\
\hline March & $30-45 \%$ \\
\hline April & $30-45 \%$ \\
\hline May & $30-45 \%$ \\
\hline June & $30-40 \%$ \\
\hline July & $30-40 \%$ \\
\hline August & $30-40 \%$ \\
\hline September & $30-40 \%$ \\
\hline October & $30-40 \%$ \\
\hline November & $30-40 \%$ \\
\hline December & $28-40 \%$ \\
\hline January 2005 & $27-40 \%$ \\
\hline February & $27-40 \%$ \\
\hline March & $27-40 \%$ \\
\hline April & $27-40 \%$ \\
\hline May & $27-40 \%$ \\
\hline June & $27-40 \%$ \\
\hline July & $27-40 \%$ \\
\hline August & $27-40 \%$ \\
\hline September & $27-40 \%$ \\
\hline October & $27-40 \%$ \\
\hline November & $25-40 \%$ \\
\hline December & $25-40 \%$ \\
\hline January 2006 & $25-40 \%$ \\
\hline February & $25-40 \%$ \\
\hline March & $25-40 \%$ \\
\hline April & $25-40 \%$ \\
\hline May & $25-40 \%$ \\
\hline June & $25-40 \%$ \\
\hline July & $25-40 \%$ \\
\hline August & $25-40 \%$ \\
\hline September & $25-40 \%$ \\
\hline October & $25-40 \%$ \\
\hline November & $25-40 \%$ \\
\hline December & $25-40 \%$ \\
\hline January 2007 & $25-40 \%$ \\
\hline February & $25-40 \%$ \\
\hline March & $25-40 \%$ \\
\hline April & $25-40 \%$ \\
\hline May & $25-40 \%$ \\
\hline
\end{tabular}

Source: The Brookings Institution, Iraq Index, www.brookings.edu/iraqindex. 